\title{
Edukacja medialna w wybranych państwach Europy
}

\begin{abstract}
Media education in selected European countries

Contemporary media education, which operates in various European countries, takes various forms. This article consists of 5 parts. In the first part, the general characteristics of media education were taken. On the other hand, the second part presents the contemporary demand for media education and the media competence necessary in the modern world, without which efficient and wise communication of information through modern media is difficult. The following parts describe media education in selected European countries. Thus, the third part includes media education in France, the fourth - in the United Kingdom, and the last - in Germany.

The subject presented in the article is only a sketch of the basic concepts of the presence of media education in selected European countries, and therefore requires indepth research analysis.
\end{abstract}

Key words: media education, media competence, media education of France, media education of Great Britain, media education of Germany

Łatwy dostęp do mediów wymaga dobrej edukacji medialnej dzieci oraz młodzieży. W zależności od poszczególnych krajów edukacja ta jest różnie propagowana, a wiąże się to $\mathrm{z}$ wieloma czynnikami. Również w jednych państwach kładzie się większy nacisk na jej rozpowszechnianie i edukowanie niż w innych.

Potrzeba edukacji medialnej jest bardzo istotna, bowiem media mogą stać się nośnikami zarówno wartości pozytywnych i społecznie akceptowanych, jak 
i szkodliwych. Każdy kraj jest odpowiedzialny za uwzględnienie umiejętności korzystania z mediów w programach szkolnych na wszystkich szczeblach. Kształcenie medialne odbywa się $\mathrm{w}$ ramach autonomicznych przedmiotów zwanych edukacją medialną lub poprzez ścieżki międzyprzedmiotowe zorientowane na edukację medialną.

Poza wpływem sytemu szkolnictwa w zakresie edukacji medialnej istotny wpływ ma również środowisko rodzinne, w którym dziecko się wychowuje. Poprzez naśladowanie i obserwację rodziców kształtuje swój sposób postrzegania informacji przekazywanych przez media.

\section{Charakterystyka teoretyczna edukacji medialnej}

Edukacja medialna stała się obszarem zainteresowań wielu specjalistów oraz naukowców zajmujących się różnymi dziedzinami nauki, między innymi: nauki o mediach, psychologii, socjologii czy pedagogiki. Coraz większe zainteresowanie tą formą edukacji spotykane jest wśród nauczycieli pracujących z dziećmi oraz młodzieżą. Rozumienie pojęcia edukacji medialnej jest również różnorako interpretowane. Inaczej postrzegają edukację medialną informatycy, inaczej pedagodzy, a jeszcze inaczej sami odbiorcy, którymi są uczniowie, w szczególności młodzi ludzie.

Edukacja medialna jest interdyscyplinarną dziedziną wiedzy teoretycznej i stosowanej. Wykorzystuje dorobek takich nauk, jak pedagogika, filmoznawstwo, medioznawstwo, komunikologia, wiedza o kulturze, teoria literatury, socjologia, antropologia, politologia, historia sztuki oraz estetyka ${ }^{1}$.

Wacław Strykowski definiuje edukację medialną jako „kształcenie w dziedzinie mediów w celu zrozumienia ich natury i oddziaływania oraz racjonalnego i efektywnego ich wykorzystania w sytuacjach dydaktycznych i wychowawczych. Potrzeba opanowania wiedzy związanej z oddziaływaniem mediów i umiejętności posługiwania się nimi, jako narzędziami komunikowania i rozwoju człowieka”².

Należy więc podkreślić, iż edukacja medialna jest nie tylko wiedzą o mediach, co raczej sztuką mądrego korzystania z mediów, traktowania jej jako pomocy służących do poznawania prawdy o świecie. Jest to kształcenie postawy świadomego odbiorcy mediów: aktywnego - poszukującego prawdy o świecie; selektywnego - potrafiącego wybierać oraz krytycznego - niedowierzającego i sprawdzającego

1 A. Ogonowska, Edukacja medialna: ziemia wciąż nieznana?..., „Kultura. Społeczeństwo. Edukacja” 2012, nr 1, s. 175.

2 W. Strykowski, Pedagogika i edukacja medialna w społeczeństwie informacyjnym, [w:] Edukacja medialna w społeczeństwie informacyjnym, red. S. Juszczyk, Toruń 2002, s. 18. 
wiarygodność przekazu w różnych źródłach. To trzy fundamentalne cechy dobrego telewidza, radiosłuchacza, czytelnika i internauty ${ }^{3}$.

W literaturze edukacja medialna kierowana do dzieci określana jest jako alfabetyzacja medialna. Z kolei edukacja medialna skierowana do dorosłych odbiorców nazywana jest wtórną alfabetyzacją medialną. Dorośli odbiorcy mają już ukształtowany, określony sposób odbioru treści przekazywanych przez media. Nie zawsze jest to selektywny i aktywny odbiór tego, co media przedstawiają. $Z$ tego też względu wtórna alfabetyzacja medialna jest trudniejsza do przeprowadzenia niż alfabetyzacja medialna najmłodszych odbiorców ${ }^{4}$.

Podsumowując, okazuje się, iż interpretując edukację medialną w aspekcie wychowawczym, należy ją rozumieć jako wiedzę, którą wykorzystuje się do interpretacji zawartych we współczesnych mediach.

\section{Potrzeba edukacji medialnej we współczesnym świecie a kompetencje medialne}

Jeszcze kilkadziesiąt lat temu człowiek miał ograniczony dostęp do informacji, zaś współcześnie ma zdecydowany jego nadmiar. Krążących wokół informacji jest tak wiele, że trudno jest je zebrać w całość, a jeszcze trudniej zweryfikować, które z nich są prawdziwe, ważne i aktualne. Obecny świat wypełnia natłok informacyjny. Dlatego tak ważne jest umiejętne i rozsądne korzystanie z mediów w funkcjonowaniu, które można wykształcić poprzez dostępną edukację medialną.

Realizacja wychowawczego celu edukacji medialnej jest niezwykle ważna dla ochrony niezakłóconego rozwoju najmłodszego odbiorcy mediów, jakim jest dziecko. Treści przekazywane przez media mają ogromny wpływ na modelowanie jego postaw i zachowań, dlatego rozwijanie właściwych postaw to najważniejsze zadanie wychowania medialnego ${ }^{5}$.

Edukacja medialna winna mieć miejsce szczególnie tam, gdzie najczęściej korzystamy z mediów, a więc w domu i rodzinie. Dopiero w następnej kolejności powinna być zadaniem szkoły oraz państwa. Jednak trudno powierzyć wychowanie do mediów wyłącznie rodzicom ${ }^{6}$. Edukacja ma pomóc dzieciom, aby nie zagubiły się w medialnym świecie, gdzie przeciążone niesprawdzonymi informacjami oraz niewiarygodnymi doniesieniami mogą stać się biernymi konsumentami mediów i wchłaniać wszystko to, co one im przedstawią. Edukacja medialna musi zatem

3 P. Drzewiecki, Media aktywni, dlaczego i jak uczyć edukacji medialnej, Otwock-Warszawa 2010, s. 6.

4 A. Ogonowska, Przemoc ikoniczna. Zarys wykładu, Kraków 2004, s. 102-103.

${ }^{5}$ A. Lepa, Media a postawy, Łódź 2003, s. 99.

${ }^{6}$ P. Drzewiecki, dz. cyt., s. 6. 
„dostarczyć im punktów orientacyjnych” . A dzieciństwo jest najistotniejszym czasem tworzenia się zrębów osobowości dziecka. Proces socjalizacji najmłodszych odbiorców dopiero się u nich rozpoczyna, a treści medialne są jednym z ważniejszych czynników, które mają wpływ na ich moralny rozwój. Niedojrzałość psychiczna oraz emocjonalna młodego odbiorcy, brak ugruntowanego sytemu wartości oraz dziecięcy bezkrytycyzm w odbiorze mediów sprawiają, że dziecko nie umie wybierać, wartościować i adekwatnie oceniać treści przekazywanych przez media ${ }^{8}$. Zanim więc uzyska dostęp do źródeł informacji, powinno nabyć odpowiednie kompetencje medialne, które pozwoliłyby poznać ich wiarygodność, sposoby korzystania z nich czy umiejętność odróżniania prawdy od medialnego fałszu.

Jak podkreśla Anna Kaczmarek, należy rozwijać wszystkie rodzaje kompetencji korzystania z mediów, gdyż brak zdobycia odpowiednich kwalifikacji w korzystaniu z mediów względem jakiegokolwiek z nich stanowi źródło cywilizacyjnej ułomności ${ }^{9}$. Można wyróżnić dwa rodzaje kompetencji medialnych: kompetencje intelektualno-kulturowe oraz kompetencje techniczno-praktyczne. Pierwsze z nich, czyli kompetencje społeczno-kulturowe, związane są z przygotowaniem odbiorcy mediów do świadomej i krytycznej percepcji różnego rodzaju przekazów medialnych. Z kolei kompetencje instrumentalne związane są z przygotowaniem odbiorcy do posługiwania się mediami jako narzędziami komunikowania, pracy intelektualnej i uczenia się ${ }^{10}$.

Leon Dyczewski pisze, że kompetencje medialne nabyte poprzez edukację medialną są wyposażeniem dzisiejszego człowieka w takie umiejętności, które we współczesnym społeczeństwie pomagają mu wszechstronnie korzystać z mediów dla swojego pełnego rozwoju ${ }^{11}$.

Edukacja medialna ma na celu uczyć dzieci oraz młodzież bezpiecznego i umiejętnego korzystania z mediów, szczególnie Internetu. Grzegorz Łęcicki twierdzi, iż istotnym celem edukacji medialnej jest budzenie wrażliwości i czujności odbiorców wobec otrzymywanych przekazów medialnych i uczenie takiego z nich

${ }^{7}$ J. Holtkamp, Co ogłupia nasze dzieci? Nowe media jako wyzwanie dla rodziców, Kraków 2010, s. 186.

${ }^{8}$ D. Jusiewicz, Dziecko i reklama telewizyjna, [w:] Środowiska wychowawcze i edukacja dorostych $w$ dobie przemian, red. T. Aleksander, Kraków 2003, s. 47.

9 A. Kaczmarek, Edukacja medialna wobec zagrożeń cyberprzemocy i cyfrowego wykluczenia, „Kultura. Media. Teologia” 2013, nr 13, s. 76.

${ }_{10}$ W. Strykowski, Kompetencje medialne: pojęcie, obszary, formy kształcenia, [w:] Kompetencje medialne społeczeństwa wiedzy, red. W. Strykowski, W. Skrzydlewski, Poznań 2004, s. 33-34.

${ }^{11}$ L. Dyczewski, Konieczność kompetencji medialnej w rodzinie, [w:] Rodzina, dziecko, media, red. L. Dyczewski, Lublin 2005, s. 341. 
korzystania, aby przyczyniały się do kształtowania postaw pozytywnych i pełnego rozwoju osobowości ${ }^{12}$.

Edukacja medialna dotyczy wszystkich dzieci, młodzieży oraz dorosłych. Starsze pokolenie nie jest przyzwyczajone do takiej liczby programów telewizyjnych, stacji radiowych, tytułów prasowych. Dzisiejsza młodzież dorasta w nowym, zupełnie innym, medialnym świecie. Dorośli zaś chcą pomóc, choć sami jeszcze nie potrafią się oswoić z mediami. Rodzice i nauczyciele najpierw sami powinni poznać media, by potem rozmawiać o nich ze swoimi dziećmi o obejrzanym wspólnie filmie, przeczytanym artykule czy interesującej stornie internetowej. Podstawą edukacji medialnej jest mądre planowanie wolnego czasu, by nie zajęło go w całości korzystanie z mediów. Należy również zwrócić uwagę na wartości, które proponują media ${ }^{13}$.

Istotą edukacji medialnej jest uczenie krytycznego, refleksyjnego odbioru przekazu medialnego. Człowiek myślący to człowiek świadomy, aktywny intelektualnie odbiorca mass mediów. Kształtowanie postawy aktywności wobec przekazu medialnego staje się coraz istotniejszym postulatem wysuwanym przez rozmaite instytucje i środowiska ${ }^{14}$.

Edukacja medialna jest najbardziej rozwinięta w krajach Ameryki Północnej. W niektórych krajach (szczególnie w Kanadzie i RPA) jest formą ochrony i wzmocnienia własnej tożsamości kulturowej. O potrzebie edukacji medialnej coraz częściej słyszymy w krajach Unii Europejskiej, czego dowodem są nowe dokumenty i zalecenia. Kraje starego kontynentu wprowadziły elementy wychowania do mediów do programów nauczania już w latach 70. XX w. Integracja europejska sprzyja wprowadzeniu edukacji medialnej jako powszechnego przedmiotu szkolnego ${ }^{15}$.

\section{Edukacja medialna we Francji}

We Francji edukacja medialna jest częścią wychowania obywatelskiego oraz nauczania technologii informacyjnej. Jej znaczenie szczególnie wzrosło po reformie w 2005 r., gdy do podstaw programowych wpisano cele i umiejętności związane $\mathrm{z}$ korzystaniem z mediów. Wiodącą francuską organizacją promującą wychowanie do mediów jest Centre de Laision de L'Enseignement et des Médias d'Information ${ }^{16}$.

12 G. Łęcicki, Edukacja medialna jako istotna cecha nowoczesnego społeczeństwa, „Kultura. Media. Technologia” 2010, nr 3, s. 73.

13 P. Drzewiecki, dz. cyt., s. 7-8.

${ }^{14}$ Dekret Inter mirfica o środkach społecznego przezywania myśli, [w:] Sobór Watykański II Konstytucje, dekrety, deklaracje, Poznań 1968, s. 80-82.

15 P. Drzewiecki, dz. cyt., s. 27.

16 Tamże, s. 31-32. 
Edukacja medialna we Francji zakłada nabywanie umiejętności w zakresie:

- oceniania subiektywnej lub stronniczej części przemówienia/rozprawki, opowiadania lub reportażu,

- rozróżniania argumentów racjonalnych od argumentów autorytatywnych,

- rozróżniania tego, co wirtualne od tego, co realne,

- bycia wyedukowanym do mediów, a także bycia świadomym tego, jakie miejsce media zajmują w społeczeństwie oraz jaki wpływ mają na to społeczeństwo,

- tworzenia własnych opinii oraz dopuszczania do ich podważenia ${ }^{17}$.

Wymienione umiejętności nie są nauczane w ramach oddzielnego, obowiązkowego przedmiotu szkolnego, lecz ich nabywanie rozrzucone jest po wszystkich przedmiotach. Edukacja medialna nauczana jest we Francji w sposób wielokierunkowy na wszystkich poziomach nauczania - czy to w szkole podstawowej, gimnazjum, czy szkole średniej. W przypadku tzw. matury humanistycznej można ją wybrać opcjonalnie w ramach zajęć filmowych (audiowizualnych) ${ }^{18}$.

Oswajanie dzieci i młodzieży z zagadnieniem edukacji medialnej, jak również program szkoleniowo-informacyjny $\mathrm{w}$ tym zakresie skierowane są do nauczycieli i mają we Francji długoletnią tradycję. Jest ona związana z istnieniem wcześniej wspomnianej organizacji Centre de Laision de L'Enseignement et des Médias d'Information ${ }^{19}$.

Rodzina jest we Francji docelową grupą aktywnej polityki państwa w zakresie edukacji medialnej, ze szczególnym uwzględnieniem zrównoważenia kompetencji medialnych dzieci i rodziców. Cele, które w tym kontekście powinna spełniać edukacja medialna, to:

- wzmacnianie ochrony dzieci i młodzieży: nie tylko poprzez udostępnianie rodzicom stosownych narzędzi w tym zakresie, ale też poprzez nauczanie ich, jak stosować te narzędzia w praktyce, oraz pomagając im w lepszym rozeznaniu sposobów korzystania z mediów przez dzieci,

- kładzenie nacisku na edukację obywatelską i społeczną w ramach wychowania do mediów, szczególnie ważne w kontekście coraz bardziej zindywidualizowanych sposobów użytkowania mediów,

- uczynienie z edukacji medialnej obszaru ogólnokrajowej mobilizacji, tak aby dotrzeć do wszystkich rodzin w kraju oraz uczynić z tej akcji powszechnie czytelną oraz rozpoznawalną ofertę ${ }^{20}$.

17 E. Murawska-Najmiec, Francja: Instytucje publiczne liderem edukacji medialnej, [w:] Cyfrowa przyszłość, red. J. Lipszyc, Warszawa 2012, s. 159-160.

18 Tamże, s. 160.

19 M. Borkowska, E. Murawska-Najmiec, P. Stępka, A. Woźniak, Organizacje międzynarodowe i wybrane państwa europejskie wobec edukacji medialnej, Warszawa 2010, s. 12.

20 Tamże, s. 14. 
We Francji przeważa model, gdzie telewizja publiczna realizuje zadania związane z edukacją medialną poprzez specjalistyczne kanały edukacyjne. Edukacja we Francji ma szczególnie długą i bogatą historię, a instytucje publiczne są jej niekwestionowanymi liderami, gdzie czołową rolę (także uregulowaną ustawowo) odgrywa właśnie telewizja publiczna France Télévision, a przede wszystkim jej kanał edukacyjny France 5, znany między innymi z takich programów o mediach, jak: „Arrêt sur l'image” czy „Dossier de lécran”. France 5 udostępnia również poprzez witrynę lesite.tv we współpracy z ministerstwem oświaty narodowej edukacyjne zasoby internetowe, także $\mathrm{z}$ zakresu edukacji medialnej ${ }^{21}$.

\section{Edukacja medialna w Wielkiej Brytanii}

W Wielkiej Brytanii edukacja medialna jest obecna w szkolnictwie od lat 70. XX w., głównie jako element nauczania innych przedmiotów, w tym języka angielskiego lub wychowania obywatelskiego. Już w latach 30. podejmowano próby wprowadzenia edukacji filmowej do programu szkolnego. Specyfiką brytyjskiej edukacji medialnej jest uczenie poprzez praktyczne tworzenie mediów, tzw. edukacyjna produkcja medialna. W promowanie edukacji medialnej angażują się nie tylko organizacje społeczne, nauczycielki i rodzice, ale również instytucje państwowe, szczególnie Office of Comunnication OFCOM ${ }^{22}$.

Od roku 1988 za programy nauczania odpowiedzialne jest Ministerstwo Oświaty. Zerwano wtedy z dotychczasową tradycją nakładania odpowiedzialności za tworzenie programów nauczania na lokalne władze oświatowe. Wprowadzono ogólnonarodowe obowiązkowe programy nauczania we wszystkich szkołach na terenie całego państwa. Z konieczności powstała Narodowa Rada Programów Szkolnych, która nadzoruje realizację polityki oświatowej dotyczącej programów nauczania ${ }^{23}$.

Główny nadawca publiczny - BBC - uwzględnia tematykę edukacji medialnej w całokształcie swojej działalności nadawczej. W swoim programie oferuje jednocześnie edukacyjne zasoby internetowe jako pomoc w nauce i rozwoju umiejętności cyfrowych oraz korzystania z mediów. BBC angażuje się również w liczne kampanie wspierania umiejętności cyfrowych i inicjuje je. Jedną $\mathrm{z}$ takich kampanii jest kampania Podaruj godzinę, w ramach której osobowości telewizyjne promują ideę poświęcenia jednej godziny swojego czasu na podzielenie się ze znajomymi,

${ }^{21}$ M. Federowicz, O potrzebie edukacji medialnej w Polsce, Warszawa 2015, s. 412.

22 P. Drzewiecki, dz. cyt., s. 32.

${ }^{23}$ J. Ławniczak, Edukacja medialna w szkolnych programach nauczania w Anglii i Niemczech, „Neodigmata” 2005, nr 27/28, s. 134. 
bliskimi lub sąsiadami swoimi umiejętnościami korzystania z Internetu. Z kolei brytyjski komercyjny nadawca publiczny Chanel 4 oferuje całą gamę kampanii i inicjatyw dla wspierania edukacji medialnej, takich między innymi jak Programme notes. Są to materiały towarzyszące poszczególnym programom do wykorzystania w klasie, opisujące cele poszczególnych programów kanału w odniesieniu do szkolnego programu nauczania. Na uwagę zasługuje także inicjatywa pod nazwą Breaking the news (gra słów wiadomości z ostatniej chwili sugerująca odkodowanie telewizyjnego przekazu wiadomości). W jej ramach powstają kursy online oraz inicjatywy uczące, jak powstają i jak tworzyć samemu wiadomości telewizyjne $e^{24}$.

Propozycja programowa edukacji medialnej dla dzieci w okresie wczesnoszkolnym, jaką przygotowano w Brytyjskim Instytucie Filmu, przedstawia odpowiedzi na następujące pytania/ zagadnienia:

1. Kto komunikuje i dlaczego? W odpowiedzi na to pytanie oczekuje się, że uczniowie zapoznają się z instytucjami i innymi podmiotami produkującymi media. Chodzi tu o zapoznanie się z instytucjami medialnymi, takimi jak: radio, telewizja, agencje reklamowe.

2. Jakie istnieją typy i rodzaje oraz kategorie mediów? W oczekiwaniu na odpowiedź zakłada się, że uczniowie zapoznają się z typologią mediów.

3. Jak media są projektowane i wykonywane? W tym dziale omawiane są różne techniki i technologie projektowania i wytwórczość komunikatów medialnych. Zadaniem dla ekspertów medialnych jest zapoznanie dzieci i młodzieży z technologią tworzenia mediów.

4. Skąd wiadomo, co to znaczy? Omawiane są tu problemy związane z językiem, kodem mediów, przybliżane jest znaczenie struktury i formy przekazów medialnych.

5. Kto odbiera media i z jakim skutkiem? Przedmiotem analizy $\mathrm{w}$ tym dziale jest adresat mediów. Analizuje się, do kogo docierają komunikaty i z jakim skutkiem.

6. Jakie treści przedstawiają media? Następuje tu analiza relacji, jaka występuje między komunikatami medialnymi a realną rzeczywistością. Analizuje również problematykę, jaką się podejmuje w mediach i sposób, w jaki się kreuje te zagadnienia ${ }^{25}$.

Poza organami rządowymi i podległymi im instytucjami, które kształtują kompetencje medialne społeczeństwa, w Wielkiej Brytanii funkcjonują liczne, bardzo aktywne organizacje pozarządowe, które również działają na tym polu, organizując

${ }^{24}$ M. Federowicz, dz. cyt., s. 412.

${ }^{25}$ W. Strykowski, Media i edukacja medialna $w$ tworzeniu współczesnego społeczeństwa. Media a edukacja, Poznań 2002, s. 60. 
warsztaty, seminaria, kursy oraz festiwale, czy prowadząc portale internetowe. Wymienić tu można m.in.: Centrum Badań Młodzieży i Mediów (Centre for the Study of Youth and Media), Centrum Języka Angielskiego i Mediów (The English and Media Centre), Stowarzyszenie Edukacji Medialnej (Media Education Association - MEA), Stowarzyszenie Mediów Wspólnotowych (Community Media Association - CMA), Media Smart, Think U Know, Citizens Online, Digital Unite, Cineclub, The Nerve Centr, Trust Telewizji Wspólnotowej (Community TV Trust-CTVT) ${ }^{26}$.

\section{Edukacja medialna w Niemczech}

Zgodnie z przyjętymi rozwiązaniami prawnymi w Niemczech zarówno media, jak i w dużej mierze kwestie edukacyjne regulowane są na poziomie landów. W Bawarii edukacja medialna była przez lata rozwijana $\mathrm{w}$ ramach lekcji informatyki, na których uczniowie nabywali wiedzę, jak korzystać z Internetu, a także programów użytkowych. W październiku 2009 r. minister Bawarii ds. mediów zapowiedział wprowadzenie projektu Medienführerschein Bayern (tj.,,medialnego prawa jazdy" dla Bawarii). Zgodnie z tym pomysłem w trzydziestu szkołach podstawowych w klasach trzecich i czwartych w ramach wdrożenia pilotażowego prowadzone będą lekcje $\mathrm{z}$ zakresu kompetencji medialnej ${ }^{27}$.

Podejście do edukacji medialnej w Niemczech jest poglądem całościowym. Edukacja realizowana jest nie tylko w szkole, ale również $\mathrm{w}$ rodzinie czy kursach dokształcających, w oświacie dorosłych, a także w samych mediach. Proces ten nazywany jest w Niemczech pedagogiką medialną lub częściej wychowaniem medialnym. Za podstawowy cel wychowania medialnego Niemcy stawiają sobie przekazanie całościowego dorobku kompetencji medialnych, czyli odpowiedzialnego i krytycznego obcowania $\mathrm{z}$ mediami. Jedną z form edukacji medialnej w Niemczech są instytuty medialne znajdujące się przy władzach oświatowych każdego landu. Organizują one kursy oraz szkolenia dla młodzieży i rodziców. Z kolei dorośli mogą zasięgnąć porady specjalistów w sprawach medialnych czy wziąć udział w tworzeniu komunikatów medialnych. Instytucje te drukują różnego typu broszury informacyjne z dziedziny medialnej ${ }^{28}$.

Nie ma prawnych przepisów zachęcających bądź nakładających obowiązki na media publiczne i/lub komercyjne w zakresie działalności na rzecz edukacji medialnej ${ }^{29}$.

${ }^{26}$ M. Borkowska, E. Murawska-Najmiec, P. Stępka, A. Woźniak, Organizacje..., dz. cyt., s. 22.

27 Tamże, s. 17.

${ }^{28}$ J. Ławniczak, Edukacja medialna $w$ szkolnych programach nauczania $w$ Anglii i Niemczech, „Neodigmata” 2005, nr 27/28, s. 136.

29 Tamże, s. 19. 


\section{Zakończenie}

Edukacja medialna jest wspólnym zadaniem dwóch najbliższych dziecku środowisk: rodziny oraz szkoły. Te dwa środowiska wychowawcze można uznać za najbardziej właściwe dla edukacji medialnej. W pierwszej kolejności kompetencje te wykształcają w dziecku rodzice, a w dalszej - państwo.

Edukacja medialna w krajach europejskich jest propagowana głównie przez instytucje, organizacje rządowe lub pozarządowe. System edukacji regulowany przez dane państwo również rozpowszechnia informacje, jakie są przekazywane dzieciom w szkole w zakresie korzystania z mediów oraz szans i zagrożeń z nich płynących. Dlatego bardzo ważnym źródłem informacji na temat edukacji może być telewizja, gdzie poprzez programy edukacyjne dzieci są kształcone w tej kwestii.

\section{BIBLIOGRAFIA}

Borkowska M., Murawska-Najmiec E., Stępka P., Woźniak A., Organizacje międzynarodowe i wybrane państwa europejskie wobec edukacji medialnej, Warszawa 2010.

Dekret Inter mirfica o środkach społecznego przezywania myśli, [w:] Sobór Watykański II Konstytucje, dekrety, deklaracje, Poznań 1968.

Dyczewski L., Konieczność kompetencji medialnej w rodzinie, [w:] Rodzina, dziecko, media, red. L. Dyczewski, Lublin 2005.

Drzewiecki P., Media aktywni, dlaczego i jak uczyć edukacji medialnej, Otwock-Warszawa 2010.

Federowicz M., O potrzebie edukacji medialnej w Polsce, Warszawa 2015.

Holtkamp J., Co ogłupia nasze dzieci? Nowe media jako wyzwanie dla rodziców, Kraków 2010.

Jusiewicz D., Dziecko i reklama telewizyjna, [w:] Środowiska wychowawcze i edukacja dorostych $w$ dobie przemian, red. T. Aleksander, Kraków 2003.

Kaczmarek A., Edukacja medialna wobec zagrożeń cyberprzemocy i cyfrowego wykluczenia, „Kultura. Media. Teologia” 2013, nr 13.

Lepa A., Media a postawy, Łódź 2003.

Ławniczak J., Edukacja medialna $w$ szkolnych programach nauczania $w$ Anglii $i$ Niemczech, „Neodigmata” 2005, nr 27/28.

Łęcicki G., Edukacja medialna jako istotna cecha nowoczesnego społeczeństwa, „Kultura. Media. Technologia” 2010, nr 3.

Murawska-Najmiec E., Francja: Instytucja publiczne liderem edukacji medialnej, [w:] Cyfrowa przyszłość, red. J. Lipszyc, Warszawa 2012. 
Ogonowska A., Edukacja medialna: ziemia wciaż nieznana?..., „Kultura. Społeczeństwo. Edukacja” 2012, nr 1.

Ogonowska A., Przemoc ikoniczna. Zarys wykładu, Kraków 2004.

Strykowski W., Kompetencje medialne: pojęcie, obszary, formy kształcenia, [w:] Kompetencje medialne społeczeństwa wiedzy, red. W. Strykowski, W. Skrzydlewski, Poznań 2004.

Strykowski W., Media i edukacja medialna $w$ tworzeniu współczesnego społeczeństwa, Media a edukacja, Poznań 2002.

Strykowski W., Pedagogika i edukacja medialna w społeczeństwie informacyjnym, [w:] Edukacja medialna w społeczeństwie informacyjnym, red. S. Juszczyk, Toruń 2002. 